\title{
Isolation and relative stereochemistry of lippialactone, a new antimalarial compound from Lippia javanica
}

\author{
Margaret T. Ludere ${ }^{a}$, Teunis van Ree ${ }^{a^{*}}$, and Robert Vleggaar \\ ${ }^{a}$ Department of Chemistry, University of Venda, Private Bag X5050, Thohoyandou, 0950 Republic of South \\ Africa \\ ${ }^{b}$ Department of Chemistry, University of Pretoria, Pretoria, 0002 Republic of South Africa
}

\begin{abstract}
The aerial parts of Lippia javanica were investigated for biologically active chemical compounds present in them. Chromatographic separation of the ethyl acetate extract of the aerial parts yielded a new antimalarial $\alpha$-pyrone, lippialactone (2). Lippialactone is active against the chloroquine-sensitive D10 strain of $P$. falciparum with an $\mathrm{IC}_{50}$ value of 9.1 $\mu \mathrm{g} / \mathrm{mL}$, and is also mildly cytotoxic The relative stereochemistry of lippialactone was determined by molecular modeling based on the determination of the relative configuration by quantum mechanical GIAO ${ }^{13} \mathrm{C}$ chemical shift calculations.
\end{abstract}

Keywords: Antiplasmodial; Lippialactone; Malaria; Verbenaceae; Lippia javanica.

\footnotetext{
* Corresponding author. Tel.: +27-15-962-8262; fax: +27-15-962-4749

E-mail address: Teuns.VanRee@univen.ac.za (T. van Ree).
} 


\section{Introduction}

As part of our ongoing search for biologically active metabolites from traditional medicinal plants from the Venda area [1,2], we investigated the constituents of Lippia javanica, a woody shrub of up to two meters in height, belonging to the Verbenaceae family. Lippia javanica is commonly used in South Africa against various chest ailments, influenza, measles, rashes, stomach problems and headaches [3], depending on the traditional healer, and is therefore known as 'fever tea' or 'musudzungwane' in Tshivenda. Its essential oil (containing up to $75 \%$ piperitenone) has been found to have good insect repellent activity and has antibacterial and antiplasmodial activity [4]. In Zimbabwe and Malawi it is used mainly as a nerve tonic [5].

\section{Experimental}

\subsection{General experimental procedures}

Silica gel $(0.063-0.2 \mathrm{~mm})$ was used as stationary phase and mixtures of hexane and ethyl acetate used as mobile phase in the chromatographic separations. Silica gel preparative thin layer chromatography plates packed were used to isolate major components of the fractions from the minor ones. Thin layer chromatography plates were visualized under UV light $(240 \mathrm{~nm})$ or by spraying with anisaldehyde visualizing reagent, made up by mixing $250 \mathrm{~mL}$ ethanol, $2.4 \mathrm{~mL}$ concentrated sulphuric acid and $6 \mathrm{~mL}$ anisaldehyde. NMR spectroscopic measurements were done using a $300 \mathrm{MHz}$ Bruker spectrometer, with $\mathrm{CDCl}_{3}$ or $\mathrm{DMSO}-\mathrm{d}_{6}$ as solvent and TMS as an internal standard. 


\subsection{Method}

The plant material of Lippia javanica was harvested in Thathe Vondo village, Limpopo Province of South Africa. About $529 \mathrm{~g}$ green plant material was collected and used for this study, and a voucher specimen deposited with the Venda Herbarium.

\subsubsection{Extraction of plant material}

Leaves and stalks of Lippia javanica were dried to a total mass of $160 \mathrm{~g}$, ground to a fine powder, and extracted with ethyl acetate for about 48 hours using a Soxhlet extractor. The materials were allowed to cool to room temperature. Solid material developed in the process. The material was then filtered and the filtrate evaporated to yield a dark green residue of $9.1 \mathrm{~g}$.

The residue was redissolved in $100 \mathrm{~mL}$ ethyl acetate and washed twice with $30-\mathrm{mL}$ portions of $2 \mathrm{~N}$ aqueous $\mathrm{HCl}$, followed by two $30-\mathrm{mL}$ portions of $10 \%(\mathrm{~m} / \mathrm{v})$ aq. $\mathrm{NaHCO}_{3}$ to remove acidic and basic substances. The organic layer was washed twice with $20-\mathrm{mL}$ portions of water. Approximately $250 \mathrm{mg}$ of anhydrous sodium sulphate was added to the ethyl acetate solution and the mixture was allowed to stand for several minutes with occasional swirling. After filtration the solvent was removed using a rotary evaporator, yielding $2.8 \mathrm{~g}$ solid neutral material. 


\subsubsection{Purification and identification of extract}

The residue (2.8 g) was chromatographed on silica gel (Merck, $200 \mathrm{~g}$ ) and eluted with a hexane-EtOAc gradient. The fractions eluted with hexane, hexane-EtOAc (90:10), and hexane-EtOAc (80:20) gave phytosterols, with stigmasterol as the major component. The fractions eluted with hexane-EtOAc (70:30) and hexane-EtOAc (60:40) were further purified by flash chromatography on silica gel (Merck, $50 \mathrm{~g}$ ) eluting with hexane-EtOAc (60:40), and finally by preparative TLC with hexane-EtOAc (70:30) to yield a fraction containing $40 \mathrm{mg}$ lippialactone (2) as orange, waxy, thick oil. NMR spectroscopic data are summarized in Table 1.

Table 1 NMR data for lippialactone (1)

\begin{tabular}{|c|c|c|c|}
\hline Atom & $\begin{array}{c}\delta_{\mathrm{H}}(\mathrm{ppm}) \\
\text { multiplicity }\end{array}$ & $J, \mathbf{H z}$ & $\delta_{\mathrm{C}}(\mathrm{ppm})$, multiplicity \\
\hline 1 & - & & $163.69 \mathrm{~S}$ \\
\hline 2 & $5.99 \mathrm{ddd}$ & $9.8,2.3,1.6$ & $121.56 \mathrm{D}$ \\
\hline 3 & $6.82 \mathrm{ddd}$ & $9.8,5.2,3.6$ & $144.42 \mathrm{D}$ \\
\hline 4 & $2.38 \mathrm{~m}$ & & $29.57 \mathrm{~T}$ \\
\hline 5 & $4.82 \mathrm{ddd}$ & $9.3,5.7,5.7$ & $77.50 \mathrm{D}$ \\
\hline 6 & $5.62 \mathrm{dd}$ & $15.5,5.7$ & $131.15 \mathrm{D}$ \\
\hline 7 & $5.69 \mathrm{dd}$ & $15.5,6.5$ & $128.33 \mathrm{D}$ \\
\hline 8 & $2.29 \mathrm{~m}$ & & $33.92 \mathrm{~T}$ \\
\hline 9 & $5.10 \mathrm{~m}$ & & $70.46 \mathrm{D}$ \\
\hline 10 & $5.04 \mathrm{~m}$ & & $74.19 \mathrm{D}$ \\
\hline 11 & $5.04 \mathrm{~m}$ & & $68.77 \mathrm{D}$ \\
\hline 12 & $1.16 \mathrm{~d}$ & 6.2 & $16.39 \mathrm{Q}$ \\
\hline OAc & $\begin{array}{l}- \\
2.07 \mathrm{~s} \\
2.04 \mathrm{~s} \\
2.00 \mathrm{~s}\end{array}$ & & $\begin{array}{c}170.10 \mathrm{~S} \\
20.97 \mathrm{Q} \\
20.83 \mathrm{Q} \\
20.59 \mathrm{Q}\end{array}$ \\
\hline
\end{tabular}




\subsection{Antiplasmodial assays}

A chloroquine-sensitive strain of P. falciparum (D10) was continuously cultured [6] and parasite lactate dehydrogenase ( $\mathrm{pLDH}$ ) activity was used to measure parasite viability [7]. Chloroquine diphosphate served as a positive control and was made up in Millipore water and diluted in medium to the required concentrations. $1 \mathrm{mg} / \mathrm{mL}$ stock solutions of the plant extracts were made up in methanol $(\mathrm{MeOH})$ and water, and were diluted in complete medium on the day of the experiment. The highest concentration of $\mathrm{MeOH}$ that the parasites were exposed to was $0.5 \%$, which had no measurable effect on parasite viability. The antiplasmodial assays were performed in duplicate on a single occasion as described elsewhere [8]. The 50\% inhibitory concentration $\left(\mathrm{IC}_{50}\right)$ values were obtained from the dose-response curve, using non-linear dose-response curve fitting analyses with GraphPad Prism v.3.00 software.

\section{Results and Discussion}

\subsection{Isolation and structure elucidation}

Plant material of Lippia javanica was harvested in Thathe Vondo village, Limpopo Province. The leaves and stalks were dried, ground to a fine powder, and extracted with ethyl acetate for $48 \mathrm{~h}$ using a Soxhlet extractor. The solid material that formed on cooling was removed by filtration and filtrates evaporated to give a dark residue $(9.1 \mathrm{~g})$ that was redissolved in ethyl acetate. Washing successively with dilute acid and sodium 
bicarbonate solution produced $2.8 \mathrm{~g}$ of neutral material. Repeated chromatography as described in Experimental yielded a fraction containing $40 \mathrm{mg}$ lippialactone (1).

Lippialactone 1 was unstable and decomposed before optical rotation and IR data could be obtained. However, the structure was established from the data obtained from one and two dimensional ${ }^{1} \mathrm{H}$ and ${ }^{13} \mathrm{C}$ NMR experiments (see Table 1). Lippialactone $\mathbf{1}\left(\mathrm{C}_{18} \mathrm{H}_{24} \mathrm{O}_{8}\right)$ is a new $\alpha$-pyrone isolated from the dried leaves of L. javanica. The proton connectivity pattern was determined by analysis of the proton-proton coupling constants and the correlations observed in the ${ }^{1} \mathrm{H}-{ }^{1} \mathrm{H}$ COSY spectrum. The signals of the proton-bearing carbon atoms were correlated with specific proton resonances in a ${ }^{1} \mathrm{H}-{ }^{13} \mathrm{C}$ COSY experiment. The subsequent analysis of the two- and three-bond $\left({ }^{1} \mathrm{H},{ }^{13} \mathrm{C}\right)$ correlations in a 2D HMBC experiment allowed the assignment of the structure (1) for lippialactone (Fig. 1).

${ }^{1} \mathrm{H}$-NMR spectrometry proved invaluable in the structure determination of lippialactone (1). Proton $2-\mathrm{H}$ resonates at $\delta 5.99$ and is coupled to $3-\mathrm{H}(J=9.8 \mathrm{~Hz})$, indicative of a cis olefinic function adjacent to a carbonyl group. Proton $2-\mathrm{H}$ is also coupled by long-range coupling to the two protons attached to C-4 $\left(J_{2,4 \mathrm{ax}}=2.3 ; J_{2,4 \mathrm{eq}}=1.6\right)$. 


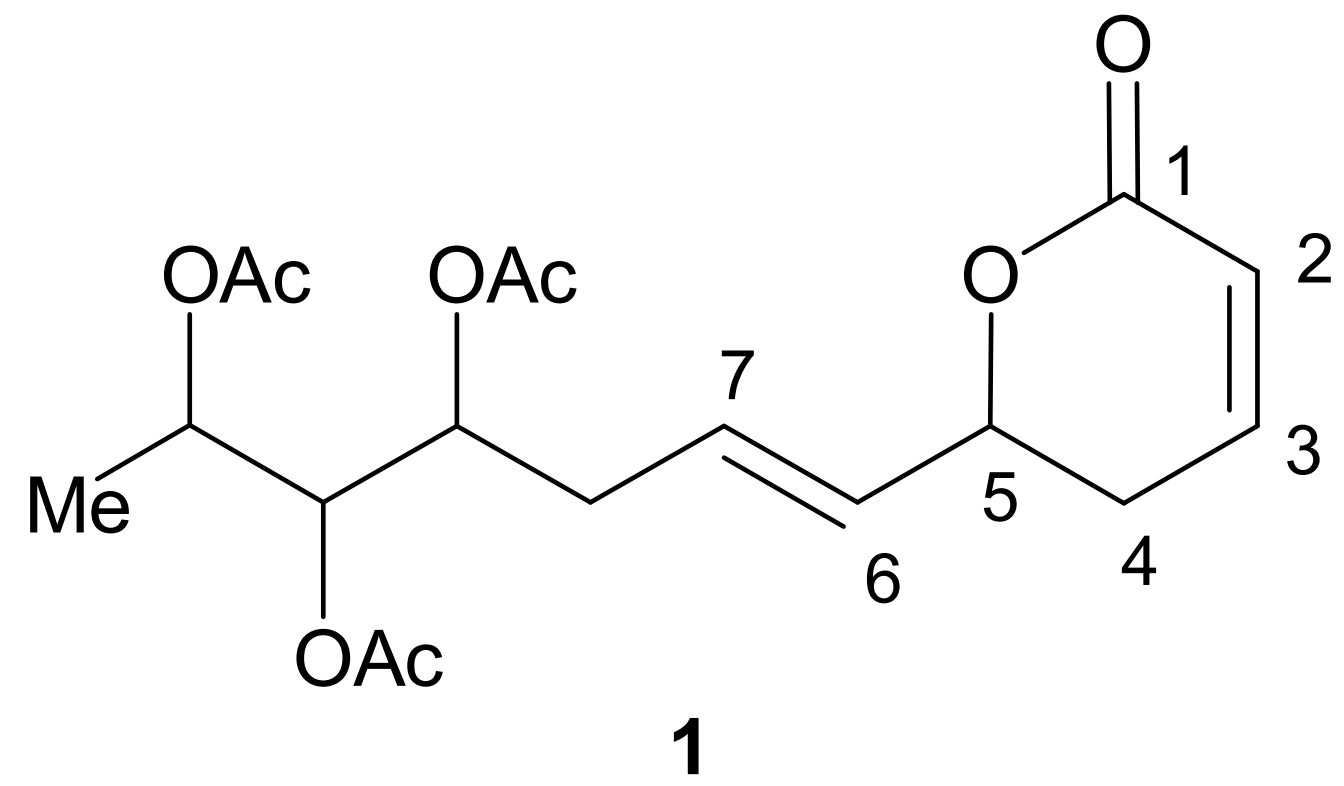

Fig. 1. Chemical structure of lippialactone (1).

The deshielding of $3-\mathrm{H}$ relative to $2-\mathrm{H}$ at $\delta 6.82$ is typical of a proton attached to the $\beta$ carbon of an $\alpha, \beta$-unsaturated carbonyl chromophore. The signal for 3- $\mathrm{H}$ appears as a double doublet of doublets from its coupling to $2-\mathrm{H}$ and also to $4_{\mathrm{ax}}-\mathrm{H}$ and $4_{\mathrm{eq}}-\mathrm{H}$. The allylic protons at C-4 are not equivalent and exhibit typical geminal coupling $\left(J_{4 \mathrm{ax}, 4 \mathrm{eq}}=10\right.$ - $15 \mathrm{~Hz}$ ) and a coupling to $2-\mathrm{H}$, to $3-\mathrm{H}$, and to $5-\mathrm{H}$. These two protons therefore resonate as a complex multiplet with chemical shift around $\delta 2.38$. A similar, complex multiplet resonating at $\delta 2.29$ points to a second methylene group. These methylene protons resonate in the ${ }^{13} \mathrm{C}$ NMR spectrum at $\delta 29.6$ and 33.9, respectively, as shown by the DEPT spectrum. The remaining resonances indicate a trans double bond (doublet of doublets at $\delta 5.62$ and 5.69 for C-6 and C-7), and the terminal methyl group (doublet at $\delta$ 1.16). Hydroxylation or acetylation shifts the remaining methine resonances $(5-\mathrm{H}, 9-\mathrm{H}$, $10-\mathrm{H}, 11-\mathrm{H})$ to $\delta 4.82-5.04$. This is confirmed by the presence of the three acetates and 
the lactone carbonyl. Finally, analysis of the COSY spectra and the two- and three-bond $\left({ }^{1} \mathrm{H},{ }^{13} \mathrm{C}\right)$ correlations in the $2 \mathrm{D}$ HMBC experiment (Fig. 2) allowed the definite assignment of the structure (1) for lippialactone.

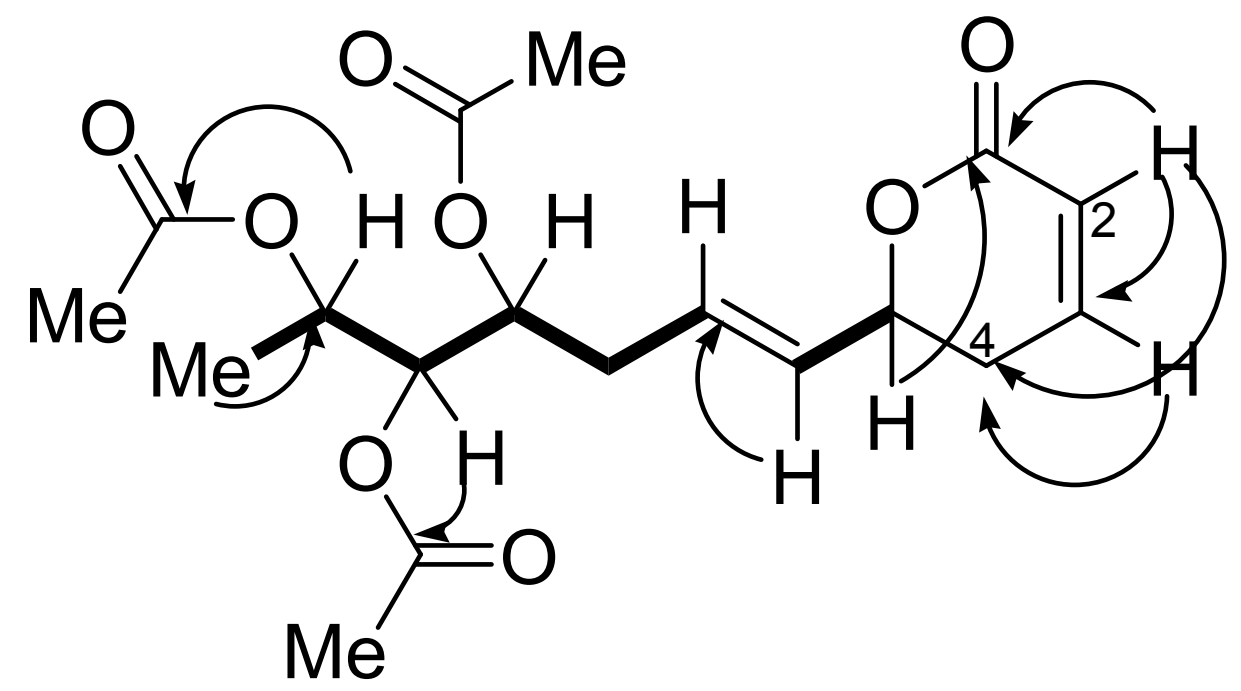

Fig. 2. The key ${ }^{1} \mathrm{H}-{ }^{1} \mathrm{H}$ COSY (-)and ${ }^{1} \mathrm{H}-{ }^{13} \mathrm{C} \operatorname{HMBC}(\rightarrow)$ correlations of compound $\mathbf{1}$.

\subsection{Biological Activity}

The essential oil of L. javanica has low activity in vitro against the Gram-positive Escherichia coli and Staphylococcus aureus at a concentration of $10 \mathrm{mg} / \mathrm{mL}$, but when the oil was tested against the D10 chloroquine-sensitive strain of Plasmodium falciparum, it gave an $\mathrm{IC}_{50}$ value of $8 \mu \mathrm{g} / \mathrm{mL}$ (chloroquine: $20 \mathrm{ng} / \mathrm{mL}$ ) [4]. Lippialactone 1 is active against $P$. falciparum with an $\mathrm{IC}_{50}$ value of $9.1 \mu \mathrm{g} / \mathrm{mL}$, and is also mildly cytotoxic. Compared to chloroquine, the compound is approximately 2000 times less active against the D10 strain of P. falciparum. 
The $\mathrm{D} 10 \mathrm{IC}_{50}$ values are listed in Table 2 and the corresponding dose-response curves are shown in Fig. 3. It is likely that minor components with a synergistic effect (or higher activity), were removed by purification of the crude fractions.
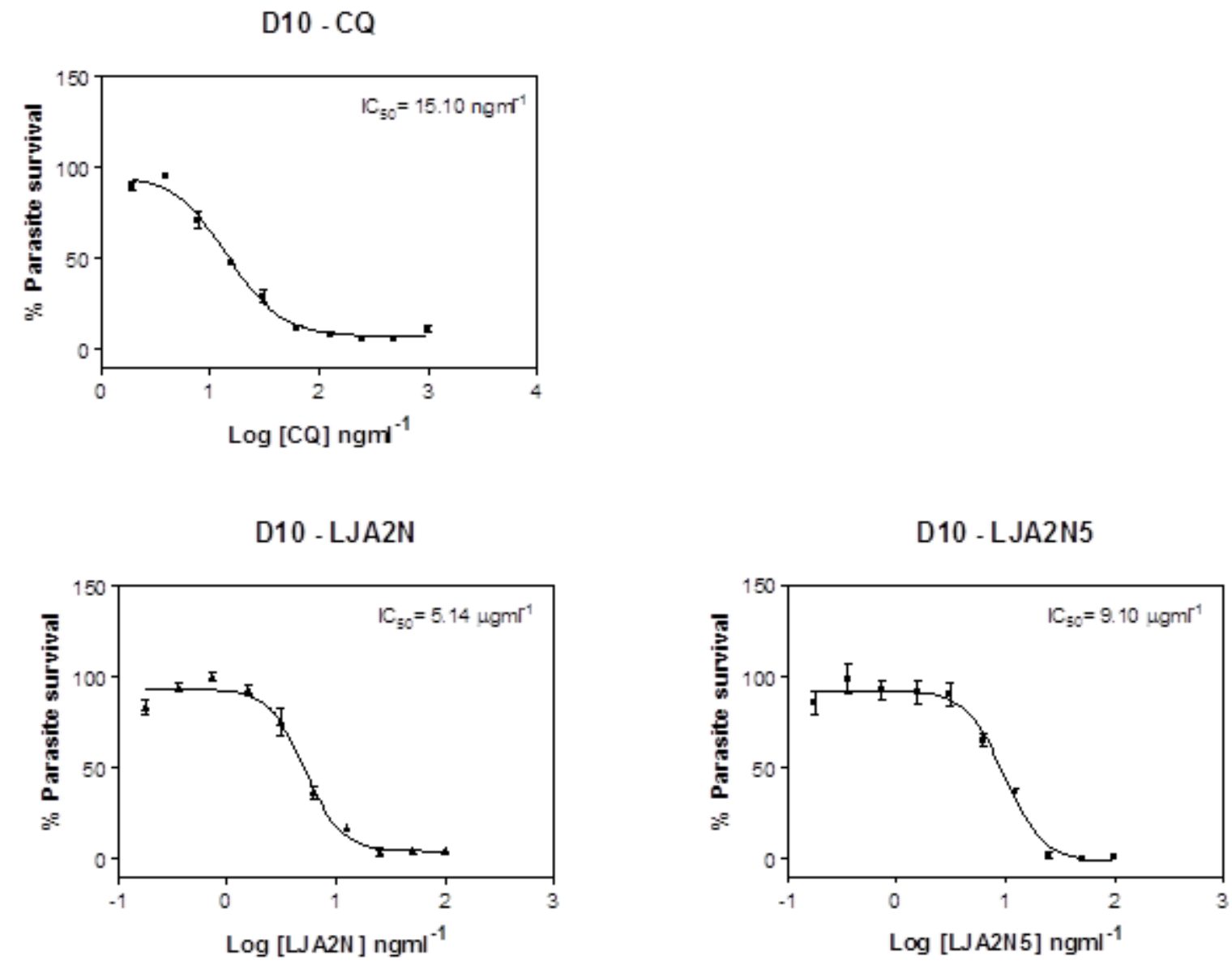

Fig. 3. Dose-response curves of chloroquine (CQ), the neutral fraction (LJA2N), and lippialactone (LJA2N5) against P. falciparum strain D10.

Table 2 In vitro antiplasmodial activity of the extracts.

\begin{tabular}{lc}
\hline Extract & ${\text { D10 } \mathbf{I C}_{\mathbf{5 0}} \boldsymbol{\mu \mathbf { g }} / \mathbf{m L}}^{-3}$ \\
\hline Chloroquine & $15.10 \times 10^{-3}$ \\
LJA2N (Neutral fraction) & 5.14 \\
LJA2N5 (Lippialactone) & 9.10 \\
\hline
\end{tabular}




\subsection{Relative Configuration}

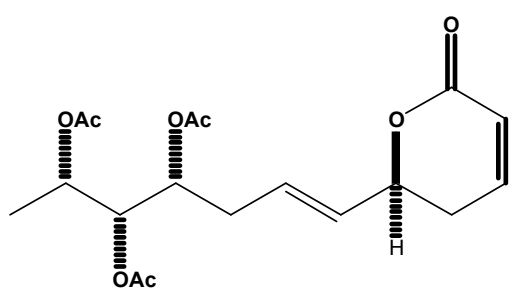

Lippia1

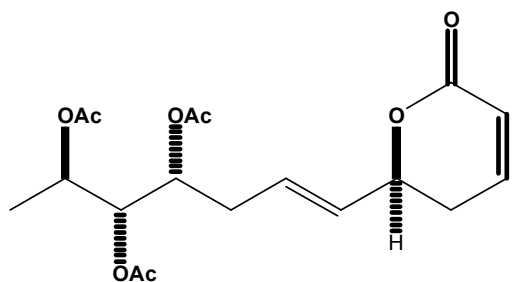

Lippia2<smiles>C[C@H](O)[C@H](OC(=O)[O-])[C@@H](C/C=C/[C@H]1CC=CC(=O)O1)OC(=O)[O-]</smiles>

Lippia3

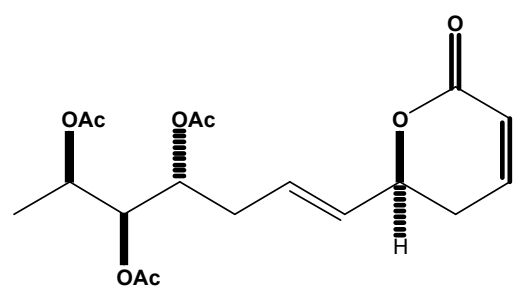

Lippia4<smiles>CC(=O)O[C@@H](OC(=O)[O-])[C@H](OC(C)=O)[C@H](C)O</smiles><smiles>CC(=O)OC(C)[C@@H](OC(=O)[O-])[C@@H](C/C=C/[C@H]1CC=CC(=O)O1)OC(C)=O</smiles>

Lippia5

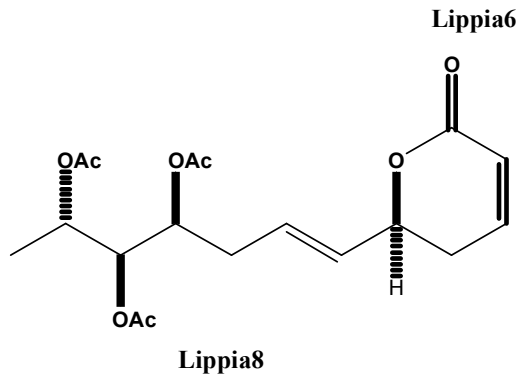

Fig. 4. The eight possible relative stereoisomers of lippialactone.

In the absence of any conclusive $\mathrm{CD}$ or chemical evidence we decided to apply molecular modelling methodology [9] based on the determination of the relative configuration of flexible compounds by quantum mechanical GIAO ${ }^{13} \mathrm{C}$ chemical shift calculations, to suggest a possible most likely relative configuration. The approach consists of (i) the modelling of all the possible relative stereoisomers (Fig. 4) of lippialactone, (ii) a geometry optimization of these stereoisomers, (iii) the GIAO ${ }^{13} \mathrm{C}$ chemical shifts calculated for each stereoisomer, and (iv) the comparison of the ${ }^{13} \mathrm{C}$ chemical shifts calculated for each stereoisomer, with those obtained for the natural product. 
Table 3 Regressions of theoretical chemical shifts on the measured ones for lippialactone.

\begin{tabular}{|c|r|}
\hline Structure & \multicolumn{1}{|c|}{$\begin{array}{c}\text { Correlation } \\
\text { coefficient, } \mathbf{R}^{\mathbf{2}}\end{array}$} \\
\hline Lippia1 & 0.9989 \\
\hline Lippia2 & 0.9973 \\
\hline Lippia3 & 0.9986 \\
\hline Lippia4 & 0.9984 \\
\hline Lippia5 & 0.9985 \\
\hline Lippia6 & 0.9982 \\
\hline Lippia7 & 0.9986 \\
\hline Lippia8 & 0.9986 \\
\hline
\end{tabular}

The GIAO calculations were performed at the B3LYP/6-31g(d,p) basis set using the Gaussian 98W software package [10]. The measured chemical shifts are listed in Table 1. Regressions of the theoretical chemical shifts on the measured ones for lippialactone produced the $\mathrm{R}^{2}$ values listed in Table 3 . Analysis of these data suggests that structure Lippia1 may be the best candidate for fitting the experimental data, but it should be pointed out that the differences in $\mathrm{R}^{2}$ are very small. A comparison (Fig. 5) of the mean absolute errors, expressed in $\Delta \delta$ units, of the calculated chemical shifts versus lippialactone, resulted in the lowest value of 3.82 for structure Lippia1, which is in agreement with the $\mathrm{R}^{2}$ value obtained. A comparison (Fig. 6) of the absolute errors for structures Lippia1 to Lippia8 relative to each of the carbon atoms again shows the calculated carbon resonances of Lippia1 to be in good agreement with those of the natural product. 


\section{C-13 Chemical Shift Difference}

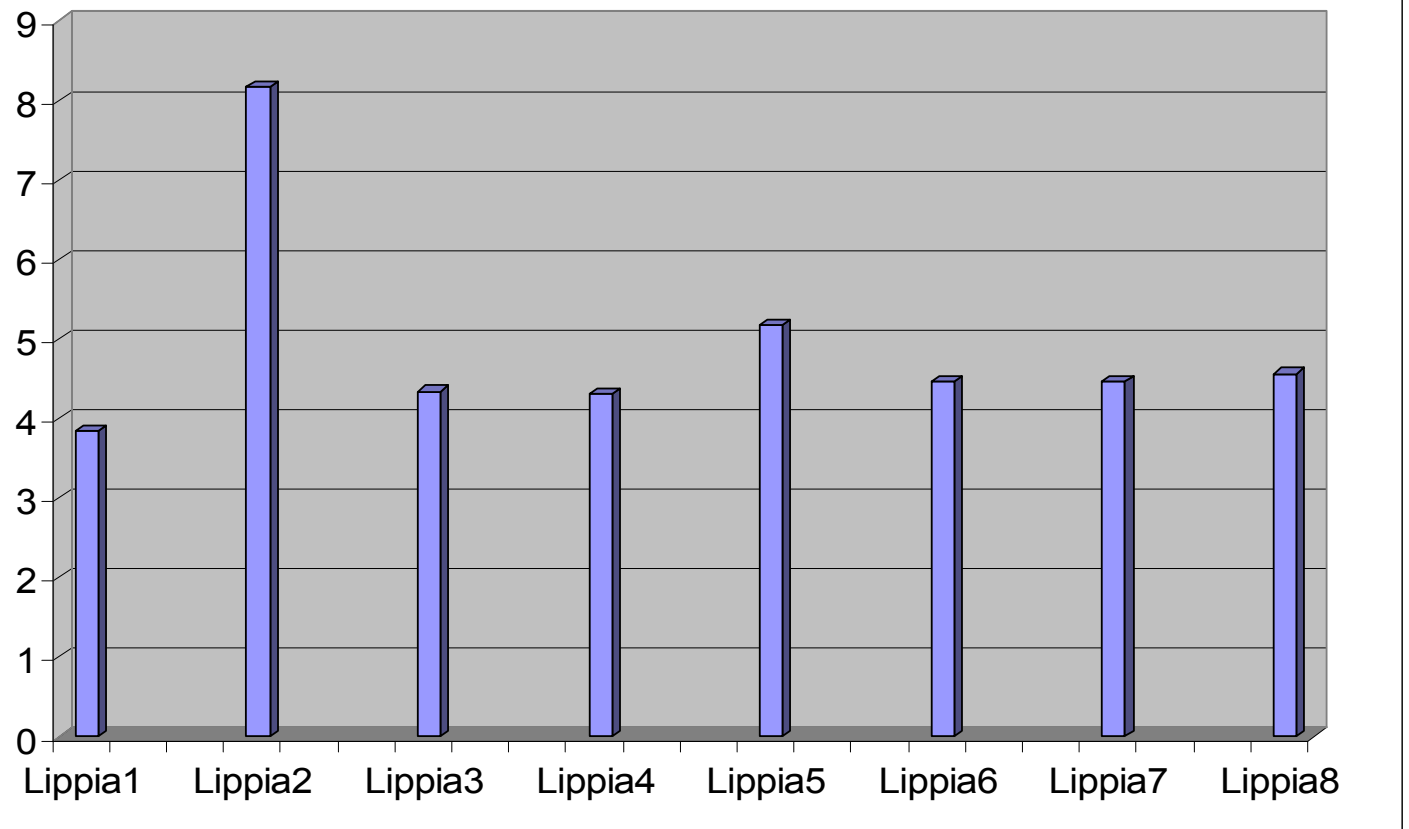

Fig. 5. Mean absolute errors found for the ${ }^{13} \mathrm{C}$ NMR calculated chemical shifts of compounds Lippia1 to Lippia8 versus the experimental values for lippialactone.

To summarize, structure 2 (Fig. 7) (or its enantiomer) is proposed for the relative configuration of lippialactone. The proposed $5 R$ configuration for lippialactone is in agreement with the configuration of this stereogenic centre in several other naturally occurring lactones [11,12]. It is therefore a diastereomer of synargentolide A [13] and closely related to $\delta$-lactones such as hyptolide [14], spicigerolide [15], synrotolide [16], passifloricin A [17,18], anamarine [19], and strictifolione [20]. The traditional medicinal uses of this plant $[4,21]$ and several other Lippia species [22] are justified. 


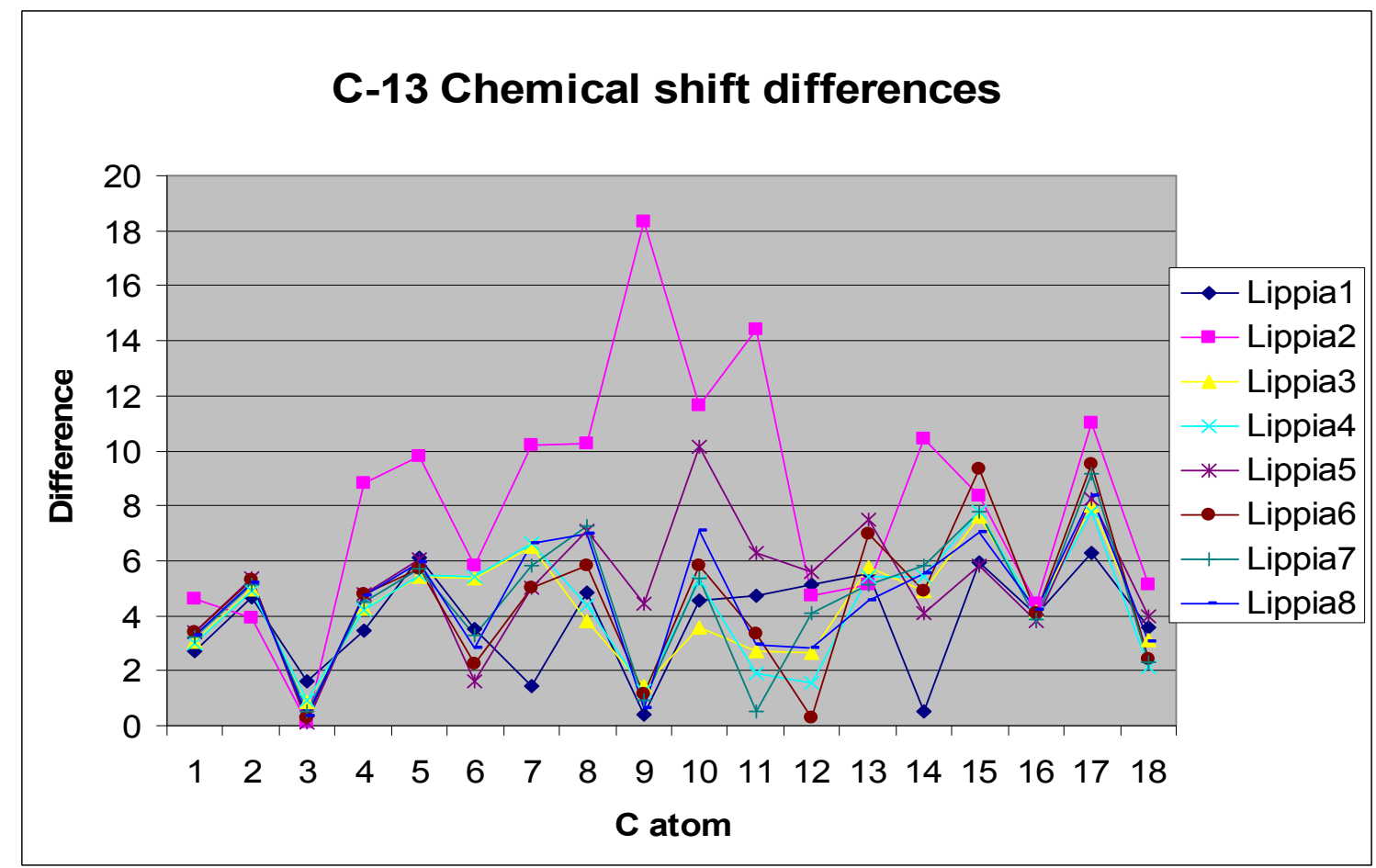

Fig. 6. Differences in absolute values for the calculated (Lippia1 to Lippia8) versus experimental ${ }^{13} \mathrm{C}$ NMR chemical shifts of lippialactone.

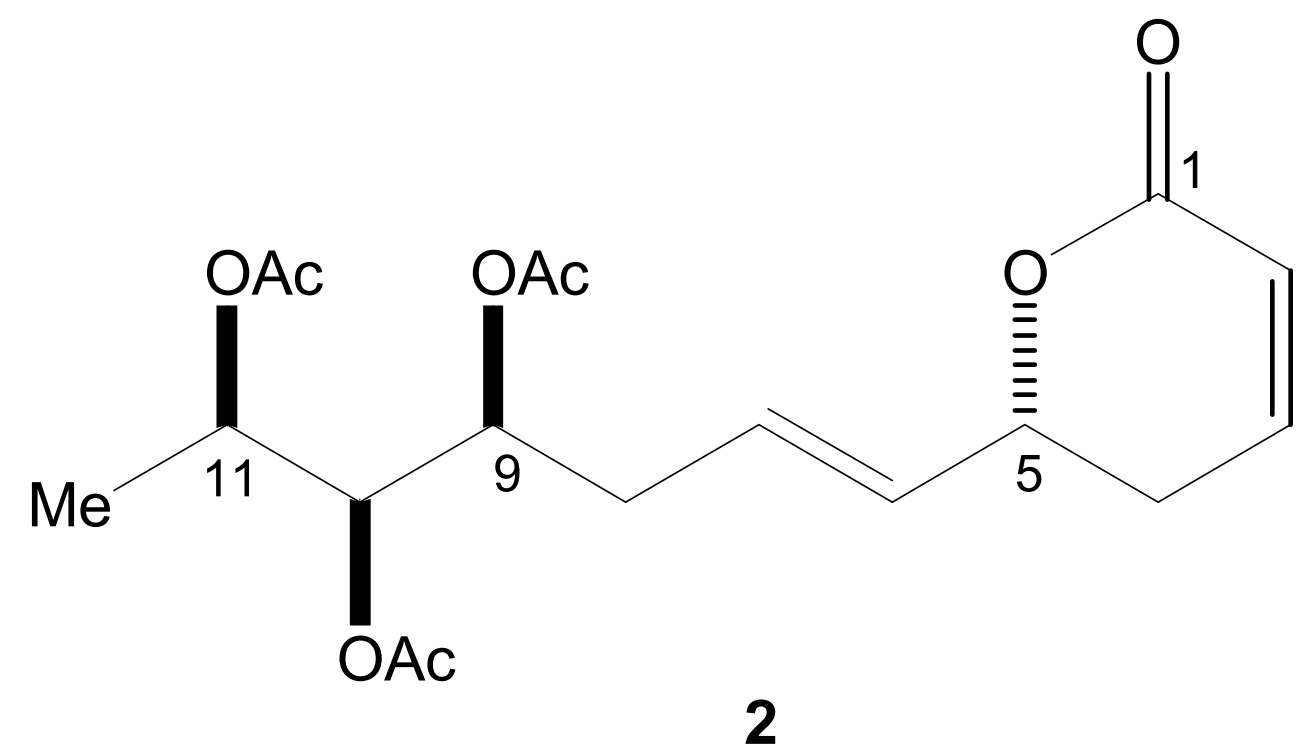

Fig. 7. Relative stereochemistry of lippialactone 2. 


\section{Acknowledgements}

This work was supported by the National Research Foundation. We are also indebted to Prof. Peter Smith (University of Cape Town) for the antimalarial testing.

\section{References}

[1] M.J. Mashimbye, F.N. Mudau, P. Soundy, T. van Ree, A new flavonol from Athrixia phylicoides (Bush Tea), S.A. J. Chem. 59 (2006) 1-2.

[2] H.F. Makofane, N. Potgieter, T. van Ree, Die verbindings en biologiese aktiwiteit van Thamnosma africana, S.A. Tydskr. Natuurwet. Tegnol. 25 (2006) 138-148.

[3] B.-E. van Wijk, B. van Oudtshoorn, N. Gericke, Medicinal Plants of South Africa, second ed., Briza, Cape Town, 2000, p. 168-169.

[4] N.J. Manenzhe, N. Potgieter, T. van Ree, Composition and antimicrobial activities of volatile components of Lippia javanica, Phytochemistry 65 (2004) 2333-2336.

[5] M. Tredgold, H.M. Biegel, S. Mavi, H. Ashton, Food plants of Zimbabwe with old and new ways of preparation, Trustees of the National Museums and Monuments of Zimbabwe, Harare, Zimbabwe, 1996, p. 72.

[6] W. Trager, J.B. Jensen, Human malaria parasites in continuous culture, Science $193(1976) 673-675$.

[7] M.T. Makler, J.M. Ries, J.A. Williams, J.E. Bancroft, R.C. Piper, B.L. Gibbins, D.J. Hinrichs, Parasite lactate dehydrogenase as an assay for Plasmodium falciparum drug sensitivity, Am. J. Trop. Med. Hyg. 48 (1995) 739 - 741. 
[8] C. Clarkson, W.E. Campbell, P. Smith P, In Vitro Antiplasmodial Activity of Abietane and Totarane Diterpenes Isolated from Harpagophytum procumbens (Devil's Claw), Planta Med. 69 (2003) 720-724.

[9] G. Barone, D. Duca, A. Silvestri, L. Gomez-Paloma, R. Riccio, G. Bifulco, Chem. Eur. J. 8 (2002) 3240-3245.

[10] M.J. Frisch, G.W. Trucks, H.B. Schlegel, G.E. Scuseria, M.A. Robb, J.R. Cheeseman, V.G. Zakrzewski, J.A. Montgomery, Jr., R.E. Stratmann, J.C. Burant, S. Dapprich, J.M. Millam, A.D. Daniels, K.N. Kudin, M.C. Strain, O. Farkas, J. Tomasi, V. Barone, M. Cossi, R. Cammi, B. Mennucci, C. Pomelli, C. Adamo, S. Clifford, J. Ochterski, G.A. Petersson, P.Y. Ayala, Q. Cui, K. Morokuma, D.K. Malick, A.D. Rabuck, K. Raghavachari, J.B. Foresman, J. Cioslowski, J.V. Ortiz, A.G. Baboul, B.B. Stefanov, G. Liu, A. Liashenko, P. Piskorz, I. Komaromi, R. Gomperts, R.L. Martin, D.J. Fox, T. Keith, M.A. Al-Laham, C.Y. Peng, A. Nanayakkara, M. Challacombe, P.M.W. Gill, B. Johnson, W. Chen, M.W. Wong, J.L. Andres, C. Gonzalez, M. Head-Gordon, E.S. Replogle, J.A. Pople, Gaussian 98, Revision A.8, Gaussian, Inc, Pittsburgh PA, 1998.

[11] M.T. Davies-Coleman, E.A.R. Douglas, Phytochemistry 26 (1987) 3047-3050.

[12] For example: M.T. Davies-Coleman, D.E.A. Rivett, Progress in the Chemistry of Organic Natural Products 55 (1989) 1; M.T. Davies-Coleman, R.B. English, D.E.A. Rivet, Phytochemistry 26 (1986) 1497; S.E. Drewes, B.M. Sehlapelo, M.M. Horn, R. Scott-Shaw, P. Sandor, Phytochemistry 38 (1995) 1427. 
[13] L.A. Collett, M.T. Davies-Coleman, D.E.A. Rivett, S.E. Drewes, M.M. Horn, Phytochemistry 44 (1997) 935 (synargentolide A structure revised in: G. Sabitha, P. Gopal, C.N. Reddy, J.S. Yadav, Tetrahedron Lett. 50 (2009) 6298-6302).

[14] S. Achmad, T. Høyer, A. Kjær, L. Makmur, R. Norrestam, Acta Chem. Scand. B 41 (1987) 599-609.

[15] R. Pereda-Miranda, M. Fragoso-Serrano, C.M. Cerda-García-Rojas, Tetrahedron 57 (2001) 47-53.

[16] M.T. Davies-Coleman, R.B. English, D.E.A. Rivett, Phytochemistry 26 (1987) 1497-1499.

[17] G. Bifulco, L. Gomez-Paloma, R. Riccio, Tetrahedron Lett. 44 (2003) 7137-7141.

[18] J. Murga, J. García-Fortanet, M. Carda, J.A. Marco, Tetrahedon Lett. 44 (2003) 7909-7912.

[19] A. Alemany, C. Márquez, C. Pascual, S. Valverde, M. Martínez-Ripoll, J. Fayos, A. Perales, Tetrahedron Lett. 20 (1979) 3583-3586.

[20] L.D. Juliawaty, Y. Watanabe, M. Kitajima, S.A. Achmad, H. Takayama, N. Aimi, Tetrahedron Lett. 43 (2002) 8657-8660.

[21] A.M. Viljoen, S. Subramoney, S.F. van Vuuren, K.H.C Başer, B. Demirci, J. Ethnopharmacol. 96 (2005) 271-277.

[22] M.E. Pascual, K. Slowing, E. Carretero, D. Sánchez Mata, A. Villar, J. Ethnopharmacol 76 (2001) 201-214. 